\title{
James McAuley's Verse Collection Music Late At Night: Poems 1970-1973 and Georg Trakl's Poetry
}

\author{
Igor Maver
}

\section{Abstract}

The article discusses James McAuley's translations of the poems by the Austrian poet Georg Trakl (1887-1914), as well as the latter's influence on McAuley's own late verse in Music Late at Night: Poems 1970-1973. This is especially true of Trakl's collection of verse Music in the Mirabell Garden translated by McAuley. Some of James McAuley's early and later work also bears an indelible stamp of Trakl's poetry.

Keywords: James McAuley, Georg Trakl, Australian poetry 


\section{MUSIC IN THE MIRABELL GARDEN}

James McAuley's posthumously published book of Georg Trakl's poems, rendered in his superb English translations and entitled Music in the Mirabell Garden: Georg Trakl (Trakl 1982), was published six years after the death of this acclaimed Australian poet. The 'Tasmanian' poet Gwen Harwood contributed the Introduction, Larry Sitsky supplied the music score for the accompanying book in a double set, "A song cycle for soprano and eight players", John Olsen provided the drawings, and John Winter did the editing, printing and design. John Winter's poem "Printing James McAuley during the Falklands War" (Winter 1989), another important point of reference published in the book, consists solely of three stanzas, of which the first one gives a description of his rather monotonous routine of printing that remains curiously indifferent to everything else that may happen around it, including the war. The war for the Falkland Islands between the United Kingdom and Argentina in the South Atlantic took place in the middle of 1982:

Your prose moves neither

Left nor right, but drives

Straight down the page ...

In the middle of the second stanza, however, there suddenly emerges a violent intrusion of contemporary events, whereby the previous monotony is shattered, creating a strong startling effect, art does seem to make a difference after all.

Ravens fly blood-splashed and

Stick cracked beaks through crazed

Heads of children gone silly

As geese on an Atlantic green.

Your Trakl holds steady -

Scarce a change in the copy -

But tells the horror in order

As in disorder too.

The ravens that "fly blood-splashed", and which are so frequent in Trakl's poetry, metaphorically stand for the military (British and Argentinian airplanes, raiding the Falklands and each other's navy). "Geese on an Atlantic green” could be interpreted as airplanes and soldiers-parachuters in their khaki uniforms being dropped from the sky. Still, Winter's subtle poetic puns and double-entendres in this extract are perhaps harder to grasp. What the poet must also have had in mind were John Olsen's drawings in Music in the Mirabell Garden, depicting Trakl's imagined phantasmagoric and nightmarish atmosphere, where ravens 
literally "stick cracked beaks trough crazed / Heads of children". The juxtaposition of the two situations is not without foundation: Trakl's vision was haunted by the monstrosities of the Great War, whereas Winter feels uneasy today, about the then waged Falkland War, which has been extremely rarely reflected upon in poetry. It seems as if the poet feels that McAuley's translations of Georg Trakl's lyric reflect a constant penchant for horror in human nature, by telling "the horror in order as in disorder too". Nevertheless, the final stanza brings in a more promising and optimistic tone, as it suggests a possible way out. The solution offered is art, however unconclusive its role may be in influencing and changing real life:

It is time to put the press to bed.

Tomorrow, with platen, ink damped paper,

Black art in three dimensions,

We'll try to set things right.

As mentioned earlier, the Australian composer Larry Sitsky completed the music score for Music in the Mirabell Garden in December 1977, and it should be noted that it was commissioned by the German Goethe Institute in Australia. A separate book of music sheets, the photocopies of Sitsky's manuscript, thus accompanies the translations. Sitsky makes a specific point in the Prefatory Note by saying that "verbal, visual and auditory effects were intended to merge". His Programme Note gives a good insight into the genesis of the book:

The translations from Georg Trakl are by the eminent Australian poet James McAuley; only a few short months before McAuley's death, I corresponded with the poet, and outlined my desire to see some of his Trakl translations. McAuley not only sent me a great number of these translations but also a long text of a special broadcast he had prepared dealing with Trakl, a poet with whom he closely identified for many years. My librettist, Gwen Harwood, considers these translations to be among the best available of Trakl in the English language.

Indeed, Sitsky and Harwood have had a long-standing collaboration in musical projects. As Harwood points out in the Introduction, Sitsky's first opera from 1965 was modelled on the eponymous Edgar Allan Poe's horror story and is titled The Fall of the House of Usher (the early Trakl's prose is likewise very much reminiscent of Poe), while the second one was titled Lenz (1970), describing "the breakdown of a poet's mind".

Affinities between Trakl and Sitsky are numerous. Gwen Harwood in the Introduction gives a short biography of Trakl in his native Salzburg, including the incestuous relationship with his younger sister Margarete (James McAuley in his essay on Trakl uses the diminutive name Gretl (McAuley 1975). Both Grete and 
Georg were throughout their lives persecuted by the fear of madness, they were said to have been involved in an incestuous relationship in which she was not strong enough to resist and committed suicide, but Trakl's family life, including his mother and his much-indebted father, was extremely complicated. The anguished and isolated Trakl, who had very early taken refuge in drugs and alcohol, was in 1914 called up as a reserve officer and a war pharmacist at the Galicia front during World War One. Overcome by the grief of his sister's death and the victims of the battle of Grödek, which he so movingly depicted in his poem "Grödek", he was taken to a military hospital in Cracow mentally disturbed, and there he poisoned himself at the age of 27. Parallel traits can certainly be drawn between him and the English 'Trench' Poets, who describe the atrocities of French battlegrounds and their battle trenches.

James McAuley himself commented on the reasons for being attracted to Trakl' s sometimes difficult and hermetic poetry laden with despair. It was his "intense longing for redemption" that drew him to Trakl, McAuley admits (cf. Harwood), quoting his own poem "The Tomb of Heracles":

Look, cranes still know their path through empty air;

For them their world is neither soon nor late;

But ours is eaten hollow with despair.

The main feature that drew McAuley to Trakl, then, was the image of the world as decay, death and utmost despair, although the fons et origo of these, of course, is to be looked for elsewhere with both poets. Harwood (1982) is also quite right in emphasizing Trakl's "image-filled expressionist poetry", in which images interact as colours in a painting often resulting in strong synesthetic effects. The Symbolist, later even Expressionist and above all Romantic-Decadent quality of both Trakl's and the late verse by McAuley is one of the common features of both. McAuley's indebtedness to Trakl's usage of the so-called "colour-language" (Macainsh 1985) is discussed here, as well as McAuley's translations partly in a thematic comparison with their German originals (see Macainsh 1984). McAuley's poetic response to Trakl's poetry is examined as reflected in McAuley's collection Music Late at Night: Poems 1970-1973, published posthumously in December 1976, two months after the poet's death (McAuley 1976).

\section{MCAULEY'S VERSE SYMBOLISM AND DECADENCE}

Carmel Gaffney examined Trakl's impact on McAuley's later poetry and finds that contrasts rather than similarities are, in fact, more obvious between them (Gaffney 1976). She further maintains that "both are also aware of the divided 
soul caught helplessly between despair and affirmation"(Gaffney 1976, 407). True, Trakl and McAuley are good examples of divided "Romantic souls in agony". Important issues were raised by Noel Macainsh, namely that McAuley's later verse can be directly linked with his early poems, when the poet was very much under the influence of two other Austrian poets: Rainer Maria Rilke and Stefan George (Macainsh 1985, 331). This is true of McAuley's short statements, pauses that separate the description of individual impressions and especially the adoption of George's punctuation, i. e. full-stops between the enumerated or juxtaposed impressions from the natural landscape: "The late sky clears ... wet pavements shine ..." (McAuley 1975, 204). Macainsh points out that McAuley was fully aware of this connection:

It seems that in the last decade I have some full circle back to the kind of poem I began with, but with a greater depth of experience which has brought me closer to fulfilling the persistent desire to write poems that are lucid and mysterious, gracefully simple, but full of secrets, .... (Ibidem.)

James McAuley's early poems were since 1935 until 1938 for the most part published in the University of Sydney literary magazine Hermes. Apart from the parallels on the simply formal level, one can notice a certain continuation as far as themes and the mood of the poems are concerned. By 1936 the themes of woeful passion, love and death emerged in his verse, showing strong, sombre influences of the French Symbolists in which despair is also one of the basic traits as in Music Late at Night: Poems 1970-1973 (1976), not to forget the visible use of symbolic elements, coupled with subtle colour language. The last line in French in $\mathrm{McAu}-$ ley's "Broken Incantation" (1936), for example, is taken from Jean Moréas's famous poem "Nevermore":

(Blood, blood on the lips and on the eyes,

Blood in the heart in the brain!)

Come away, come away, my beloved,

For the springtime is over and gone

Et l'hiver fauche sur les landes. (McAuley qtd in Coleman 1980, 7)

Not only can the link between the Symbolists (Paul Verlaine, Arthur Rimbaud) and James McAuley be drawn along these lines, for the Decadent late Romantics, too, represented a significant source for the young and the old McAuley. In 1938 he wrote an MA thesis on the Symbolist poets and was very much familiar with the French Decadent poets, especially Charles Baudelaire, on whom McAuley modelled some of his early works: "Ange Plein de Gaîte" from 1938, for example, takes its theme from Les Fleurs du Mal, No. XLV, from Baudelaire's poem "Réversibilité". 
In a book on McAuley, Leonie Kramer gives a historiography of his interest in Trakl. McAuley translated his first poem "Winter Nightfall" ("Ein Winterabend") in 1958 (Kramer 1988, xviii), returning to him only in 1970, saying that Trakl had produced "perhaps the finest poetry written in our century" (Ibidem.). Kramer comments upon McAuley's essay "The Poetry of Georg Trakl”, which includes several translated poems and where McAuley draws a clear distinction between Trakl's early lyrical pieces and the later Expressionist poems, echoing a very personal, expressive, clearly subjective and distorted vision of reality inspiring pain and fear of the imminent Great War, the suffering and casualties it brought, and its aftermath. Although Trakl wrote over one hundred poems, McAuley was solely interested in the lyrical ones. It should be emphasized that McAuley's remark about Trakl's Decadence mostly eluded critical reviews of McAuley's work. He himself writes that in Georg Trakl's work "traces of the stage properties of early twentieth-century literary Decadence linger here and there" (McAuley 1975, 202). The Decadent and Symbolist quality most certainly helped to incite $\mathrm{McAu}-$ ley to translate the Austrian poet from Salzburg, considering Art as a contemplative refuge from the world of strife and pain. As a result of the desire for an artistic haven, Symbolist poetry showed a keen sense of mortality and a sense of the malign power of sexuality.

\section{MUSIC LATE AT NIGHT: POEMS 1970-1973}

Looking closely at James McAuley's poems from Music Late at Night: Poems 1970-1973 (McAuley 1976) in terms of the affiliations it has with Trakl's poems in McAuley's translation from Music in the Mirabell Garden (McAuley 1982), there are some distinct characteristics of poetic diction hold true for both poets. In the opening poem "World on Sunday" there are an irregular but still very persistent use of rhyme, short statements, powerful Imagist imagery with Impressionist undertones, and a recurrent use of the image of the moon set against the ever-changing sky, both taking on explicitly symbolic significance:

Brown lilac, roses filled with rain;

Hayfever streaming off mown grass ...

Disordered beds where we have lain;

Life and death offered at Mass; ...

It isn't easy to explain.

I turn back from the sunset stain.

A huge moon yellow like dull brass

Lengthens my shadow down the lane.

(Music Late at Night 3) 
A huge moon, "yellow like dull brass", bears an ominous significance for the poet, "lengthening his shadow" and thus reducing his existence from a real human being to a shadow. The reference to the "sunset stain" is interesting, for the common stock metaphor from the Romantic arsenal is turned upside down. Generally pleasant is, for the speaker, the "stain" of Man's mortality, a sight one should turn away from. On the other hand, the simile used for comparing the moon to dull brass is not all that startling, but its recurrent use makes it a symbol in the collection.

"Nocturne" is a beautifully rendered Impressionist depiction of the melancholic feeling with the absent poetic persona. This time the setting is clearly set in Australia, probably McAuley's Tasmania. It should be said that McAuley tried to balance out the European/Salzburg settings of the poems in the discussed collection by moving freely between the Salzburg and Australian locales, to no detriment of the poems themselves. Moreover, this procédé highlights the 'Mirabell' poems much more effectively against the Australian pieces. We see the gull fly and casuarinas sigh, while the omnipresent moon is, once again, "congealed in cloud", where it hangs motionless:

A gull flies low across the darkening bay.

Along the shore the casuarinas sigh.

Resentful plovers give their ratcheting cry

From the mown field scattered with bales of hay.

The world sinks out of sight.

The moon congealed

In cloud seems motionless.

The air is still.

(Music Late at Night 5)

In the poem "Private Devotions" we see the poet's characteristic treatment of the moon. The grey clouds are still there, but it is essential to note the poet's possible reference to Percy Bysshe Shelley and his short lyrical "The Waning Moon", which by extension also determines the poet's own stance:

Gathered starlings chatter loud

In the late night; the clocktower chimes;

Ghostly-pale a full moon climbs

Out of the folds of linen cloud.

(Music Late at Night 6)

And like a dying lady, lean and pale,

Who tatters forth, wrapped in a gauzy veil,

Out of her chamber, led by the insane

And feeble wanderings of her fading brain, 
The moon arose up in the murky East, A white and shapeless mass -

(Percy Bysshe Shelley, "The Waning Moon", 1961)

The "ghostly-pale" moon thus in both cases "climbs out of her chamber", shrouded in her "gauzy veil". This is perhaps a rather unexpected image for McAuley, but its recurrent use in the collection elevates to the stature of a symbol. It can be said it stands for a hypersensitive, isolated and lonely Romantic poet, shunned by society at large because of his difference, and as a result of this, overtaken by despair. We would contend that such symbolism probably entitles us to place McAuley, regardless of other labels, also among the Neo-Romantics, particularly in his later stage. However, his Romantic quality is enriched with the elements of Symbolism, and the echoes of Decadence. It is an interesting mixture indeed, and a very successful one, too.

In "Autumn Images" clouds fill the enormous sky, whereas in the poem "Madonna" the sky "runs cracks of jagged glare". Its oppressive presence is very much reminiscent of Baudelaire's le ciel qui pèse comme un couvercle (Baudelaire 1963). The poem "Winter Drive", probably written by McAuley upon learning about the death of the Australian poet Kenneth Slessor (Coleman 1980, 108), is of seminal importance for this line of analysis, as well as a genuine lyrical neo-Romantic gem:

Fallow fields, dark pewter sky,

Steady light on the wet plain,

Evening falls in freezing rain

With a promise and a lie.

Promise in the leaden sky,

In the leaden fields' bleak shine,

In the slate vats full of wine,

In the knowledge that we die.

But the lie is in the soul,

And it rots the world we have.

Till there's nothing left to save.

Dying world and deadened sky,

Traffic roars beyond control.

What is left to make us try?

(Music Late at Night 8)

The final verse of the first stanza clearly reveals McAuley's ambivalent attitude towards despair, subsumed in the image of rotting decay, which makes it different from Georg Trakl's all-embracing pessimism. McAuley, unlike Trakl, always allows for at least a spark of hope, "a promise", although he accepts the inevitability 
of a "lie". Contrary to what one would expect, the poet still finds promise in the "leaden sky", regardless of his awareness that everybody must die. This leads us to believe that his attitude to death is rather one of stoical acceptance, very much in the sense of Michel de Montaigne's thoughts on death, suggesting that everyone should get used to the idea of dying (cf. Montaigne's essay "Sur la Mort", Essais). The double aspect and consequent interchangeability of hope and despair is in keeping with McAuley's Romantic strain, attributing the "promise" to the natural element, the sky and the landscape, however leaden they may seem. The root of all evil, the "lie", is in his view to be found in the condition bumaine of every single individuum. To die "rots the world we have" and the poet sees no immediate solution to this state. The concluding ontological question into the purpose of Man's existence thus remains merely on the rhetorical level. As it will be shown later, Trakl's attitude is different in so far as there is no trace of hope, for Trakl is caught in the impasse of the capitalized Despair and Decay, both being reflected in the landscape of his Weltschmerz that cannot be individualized.

Geographical references are, on the other hand, perfectly clear in the poem "In the Gardens", which was written during James McAuley's visit to Trakl's native Salzburg in 1973. The Mirabell castle and park (gardens) are set in the heart of the old town of Salzburg, not far from Trakl's home, now turned into a museum boasting exquisite eighteenth-century monuments from the Salzburg archi-episcopal reign, with the citadel crowning the city of spires and turrets. The gardens with its rose garden, orangerie (now a palm house) and statues (of dwarves), fountains reflect the French-type of a symmetrical jardin à la française and represent a symbol of power and glory in "a fearful symmetry" of the Baroque period of Prince-Archbishops: the garden was built in 1606 by Dietrich Wolf. The speaker of the poem "In the Gardens" practically follows in Trakl's "footprints," brooding over the transcendence of the vision of the nymph's "blank eyes", so much reminiscent of Trakl's "faun" who looks "with dead eyes after / Shadows that glide into the dark":

Softly gleams the lily-pond.

A late bee hovers round the rose. And the

gentle nymph's blank eyes Seem to seek

and see beyond

The park, the city, and the skies.

\section{(Music Late at Night 10)}

Ancestral marble has gone grey.

A birdflight wavers into space.

A faun looks with dead eyes after

Shadows that glide into the dark.

(Georg Trakl, "Music in the Mirabell Garden") 
In the next poem of the collection Music Late at Night, "Watercolour," we are suddenly transposed back to an unmistakably Tasmanian setting in which we find McAuley's masterly use of the colour-language. He juxtaposes the Mirabell Garden and a familiar garden from back home in Tasmania, growing "in the rock pools", where "over mussel-beds the tide flows". The reader notices the various shades of that are attributed to Australian setting, with the ever-present symbol of the moon rising in "darker blue". The brightness of typical Australian light and sharp contrasts that can be seen in Australian water-colour art and painting are set in contradistinction to the "soft gleam" of the Mirabell pond in Salzburg:

The sky, the bay, are filled with blue.

In the rock pools a garden grows.

Over mussel-beds the tide flows.

A cormorant sinks in the blue ...

What colours wink in the wet sand -

Sparkles of violet, green and blue?

Above a headland of dark pines

A white sea-eagle holds the view.

Whatever it was we thought we knew

Grows hazy as the sun declines.

The moon comes up in darker blue.

(Music Late at Night 11)

"Morning Voluntary" introduces the atmosphere of snow, cloudy skies and a generally cold atmosphere, of which perhaps "very little can indeed be said":

Clouds have a brown look of snow.

Cat comes limping from the shed.

The white birch with arms outspread,

Having changed its wealth for gold,

Drifts it down into the mould.

Stalky vines glow darker red ...

Very little can be said.

Cold inconstant breezes blow.

Starlings comment in a row.

Spots of black invade the red.

(Music Late at Night 12)

Leonie Kramer maintains that the colours in McAuley's poems frequently assume a liturgical significance (Kramer 1988, xxv), which can be sustained with $\mathrm{McAu}-$ ley's own statement about the colour-language and synesthesia in Trakl's poems: 
In Trakl's world, colours take on meanings. The colours of life tend to become tainted and suffused with evil suggestions: for example red, the red of blood, the red of the red blouses of girls, has often a negative value. So too has yellow. The good colours are those of heaven: the blue and gold of the sky and the sun are named as God's colours. But also white, the cold glitter of stars, or the white of bloodless flesh or ghosts, often implies a purity superior to the colours of life. (McAuley, 1975, 221)

In a Structuralist analysis Noel Macainsh, however, points out that colour is in this McAuley's collection the most significant metaphoric feature and device:

The function of colours in the late poems is not fulfilled simply in suggestions of sense impressions but also in their prompting of reflection. Colours, which are themselves general impressions, gain specific meaning from their context, from their empirical origin. (Macainsh 1985, 339)

Another possible explanation of the colour-language in "Morning Voluntary" can be given. In this poem there are three basic colours: white, identified with coldness of snow and clouds, thus representing a negative value in terms of hostile natural phenomena; red, likened to the elemental life force, energy and élan, which can, along with its creative impetus also be ultimately considered destructive for Man; and black, which seems to be the very distillation of the poeticizing subject's despair. How are we, then, to interpret the crucial and mysterious statement "Spots of black invade the red?" In the physical landscape red leaves get black autumnal spots, but the reference is also to the poet's cancer (black) infected blood (red). In the landscape of the mind, black is one aspect of his conscience, eating into his vital forces ("red spots"), massively destroying them and leaving behind but a "decay". In Bergsonian terms one could even draw a parallel between the clash of the "deep" and "surface" ego within the poet's mind, as it can be found, for example, in Stendhal's Le Rouge et le Noir or in the colour redblack imagery of Hawthorne's The Scarlet Letter. In any case, it is for each reader to project his own associations into the full understanding of the usage of colours in McAuley's discussed later verse, which, in turn, depends largely on the civilization and cultural background horizon of the reader and the significance they ascribe to each individual colour.

"Motel, Burnie" brings the reader back to Tasmania again, as well as "Saturday Morning," in which he introduces the adjective "sodden". The same epitheton ornans is employed in the next poem, "In Northern Tasmania", which depicts a pastoral idyll disturbed by an ominous "silent raven", symbolizing the poet's undercurrent of despair. The image of a raven is also used in "Saturday Morning", and one unfortunately gets the impression that it is, like the adjective "sodden", used 
all too frequently, in one poem after another. Still, the impression and sensibility of these poems is again a very Romantic one.

The concluding poems in Music Late at Night: Poems 1970-1973 are the record of James McAuley's trip to Salzburg, a veritable pilgrimage to Trakl's hometown. In his essay on Trakl he, for example, gives us direct references to the places, statues and the like he was not able to find while in Salzburg in 1973 (McAuley 1975, 222). The imagery used before is in these poems enriched by auditory effects. The church bell chimes in Trakl's and McAuley's poetry signify sadness (cf. also Rowe 2000), Weltschmerz, supposedly mourning, without precisely indicating for whom the Donne-like tolling of the bells is intended. The poem "Trakl: Salzburg II. In the Mirabell Garden" is thus directly inspired by Trakl, describing rather the "tableaux of lust and violence" in a grey Baroque marble, with the indispensable ominous bellstrokes that "pulse the air". The description of the graves, mortality and its intimations and the waning flowers in the churchyard ("Trakl: Salzburg III. In a Village Churchyard") unequivocally affiliates McAuley's poem to Gray's "Elegy Written in a Country Churchyard," which also shows McAuley's (pre)Romantic bent:

Their graves have holy-water stoups, for prayer;

And little lamps they try to keep alight

To make the bed of darkness faintly bright;

And flowers of course, renewed with constant care.

(Music Late at Night 19)

The title poem of the collection (and the last one "Autumn on the Wachau") Music Late at Night: Poems 1970-1973 bears a clearly Traklean stamp: the shades of black, white and red colours, decay, "the soulless music" of bells and clouds of grief and despair. The poet evidently wrote this poem in the small hours, when even the moon "sails cold" and the empty streets wait for the new day to commence, for a new beginning. But this time there will be no second chance, because the despair is just too overpowering, "the rigid silence is complete". The music that the speaker of the poem 'hears' in the Mirabell Gardens is the music of silence, late at night, announcing the arrival of the end, death, and strongly reflecting McAuley's knowledge of his incurable disease of which he died only three years later:

Black gashes in white bark.

The gate is clouded with spicy prunus flowers.

The moon sails cold through the small hours.

The helpless heart says, hold and wait....

Again that soundless music: a taut string, 
Burdened unbearably with grief
That smiles acceptance of despair.

(Music Late at Night 23)

Comparing Georg Trakl's poems from the book of James McAuley's translations Music in the Mirabell Garden with McAuley' Music Late at Night, only the most obvious similarities shall be pointed out as regards the use of imagery and themes, most of which are also contained in McAuley's own essay on Trakl. He devoted more than one page in the essay to Trakl's fine and probably best known poem "Grödek", speaking in greater detail about the significance of red colour:

The scene is the battlefield named in the title, with the sound of the guns, the cries of the wounded and dying, the day ending in a red sunset like the gathered blood of the slain. Night falls, the moonlight and stars appear over the battlefield; in the darkness the poet's sister appears to welcome the souls of the heroes who died in battle. (McAuley 206)

The imagery of the poem is, in fact, quite Imagistic, in its shocking concreteness, reminding us of similar procédés used by the American writer Stephen Crane, a precursor of Imagism in prose in The Red Badge of Courage:

A darker sun; night embraces

Dying warriors, the wild complaint

Of their broken mouths.

Yet quietly there gathers in the pasture-ground

Red cloud, in which dwells an angry god,

Red blood gathers, lunar coolness.

All roads lead into black corruption.

(Music Late at Night 46)

The Romantic convention of using a solitary figure walking in the natural landscape in a "pensive mood", as Wordsworth would have it, with all the senses absorbing the tiniest details, is common to both Trakl and McAuley. The poems are set in autumn and at dusk, with a cold wind blowing in a cloudy, "leaden" sky where only a "ghostly-pale" moon can occasionally be discerned. Where Trakl uses a blackbird, McAuley has a raven. Trakl's original well-known poem "Music in the Mirabell" (Trakl 1982), like most of McAuley's poems, shows the effacement of a persona, whereas the meaning is conveyed to the reader, not through statements, but rather through descriptions and musical score of the words. It can be seen on a marble table (Trakl Gedichttafel) in the Mirabell garden itself, paying homage to this site that Trakl and later McAuley visited, as well as many other poet-hunters 
and art pilgrims: it was the central poem for McAuley late verse and the one that gave rise to his Trakl translations.

\author{
"Musik im Mirabell" \\ Ein Brunnen singt. Die Wolken stehn \\ Im klaren Blau, die weißen, zarten. \\ Bedächtig stille Menschen gehn \\ Am Abend durch den alten Garten. \\ Der Abnen Marmor ist ergraut. \\ Ein Vogelzug streift in die Weiten. \\ Ein Faun mit toten Augen schaut \\ Nach Schatten, die ins Dunkel gleiten. \\ Das Laub fällt rot vom alten Baum \\ Und kreist herein durchs offne Fenster. \\ Ein Feuerschein glüht auf im Raum \\ Und malet trübe Angstgespenster. \\ Ein weißer Fremdling tritt ins Haus. \\ Ein Hund stürzt durch verfallene Gänge. \\ Die Magd löscht eine Lampe aus, \\ Das Ohr hört nachts Sonatenklänge.
}

(Georg Trakl, 1912)

Trakl's poem "Suburb in the Föhn" clearly shows his Romantic "exoticized" nature and disposition. For one thing, he introduces elements of exoticism and downright orientalism, and a wish to escape to far-away, unknown places, such as, for example, the land with the "rose-coloured mosques". The poet notices in the afternoon sky the beams of piercing sunrays, emerging through a sporadic cloud, as on the paintings by the old Flemish painters. In his daydreaming he imagines them bringing a different kind of life. We sense a "Romantic" and downright orientalist nostalgia for the mediaeval past in "fine carriages, gallant horsemen". The use of colours here possibly suggests the influence of Arthur Rimbaud, while a similar escapist theme can be found also in Trakl' s poem "Decay" ("Thus over clouds I follow those far journeys"):

Out of clouds shimmering avenues emerge,

Complete with fine carriages, gallant horsemen.

The one sees a ship run aground against cliffs,

And often there are rose-coloured mosques.

(Music in the Mirabell Garden 36) 
An example of Trakl's Decadent streak, which has surprisingly passed almost unnoticed by the critics, is the "Farm-girl". It is reminiscent of Baudelaire's depiction of the beautiful and, at the same time, rotting aspects of an object, but even more so of E. A. Poe's iconographic usage of the death of a young, beautiful woman (cf. "Annabell Lee"). The figure of the farm-girl thus appears in striking contradictions: youth - death and beauty - rotting decay. The distant tinkle of a bell, similarly to McAuley's poems, indicates the state of mourning, while the originally blue sky gets covered by "black cloths", as the farm-girl's death becomes imminent. The imagery of decay used is Imagist and Decadent again, shocking but effective indeed: her mouth is compared to a wound, buzzing with flies, which brings Baudelaire to mind ("Une Charogne", A Carrion), depicting putrefication (Baudelaire 1963, 44-46):

And the sky looked at the superb carcass

Like a flower blossoming.

The smell was so strong that there on the grass

You believed you might faint/.../.

(Charles Baudelaire, Fleurs du mal 44-46)

And the bright blue of the sky.

And the wind brings to the window

The distant tinkle of a bell.

Shadows glide across the pillow ...

She breathes heavily in her pillow

And her mouth is like a wound ...

Clouds above the silent forests

That are covered with black cloths ...

She lies quite white in the darkness.

A cooing of doves sounds under the eaves.

Like carrion in bush and darkness

Flies are buzzing round her mouth.

(Georg Trakl, Music in the Mirabell Garden 22)

However, despite several common traits between Trakl and McAuley, Decadence remains one that did not specifically attract McAuley in composing his Music Late at Night Poems: 1970-1973, albeit he chose for translation many Trakl's poems with Decadent themes and sensibility. 


\section{CONCLUSION}

The parallels and literary affiliations between the Austrian poet Georg Trakl's early lyrical poems, many of which James McAuley from Australia masterly translated into English in the book of verse translations from Trakl's verse Music in the Mirabell Garden, and McAuley's later verse from Music Late at Night: Poems 19701973, are manifold. Both poets display a 'divided' soul in a Romantic 'agony', torn between the depths of despair and (especially McAuley) affirmative hope, the reasons of which are, of course, quite different for each of the two poets, whether the loss of religious belief or awareness of illness in McAuley's case (Gaffney 1976, 408), or the emotional imbalance that is enhanced by the Expressionist feeling of guilt and the horrors of the Great War in Trakl's verse. They both use the description of the landscape, although in a much more elaborate and complex way than Eliot's concept of "objective correlative" would have it. Landscape charged with an intrinsic symbolic negative value does not merely reflect the psyche of the poet, for it also influences the poet's mind and mood (cf. Page 2014). The relationship of influence is, so it seems, a mutual one. The landscapes of despair, on the other hand, are darker in Trakl's poems, because McAuley shows a somewhat ambivalent attitude towards utmost despair and generally does not share Trakl's Expressionist violence, death, sexuality and the apocalyptic vision of the world. Both poets, however, express more than just physical reality but rather their own subjective emotional experience of the moment.

The "ghostly-pale" moon and "leaden" sky are present in the verse of both poets writing out of decay, the moon possibly representing their solitary neo-Romantic nature, isolation and outcast state, which in turn throws them into disgust (Trakl) and despair (McAuley). It is rather paradoxical to describe McAuley the poet as a neo-Romantic, especially since McAuley the critic expresses such a "commensurate distrust of the Romantic emphasis on feelings which, while it has unfortunate tendencies to undervalue the expression of strong personal feeling in works of literature, is justified to the extent that it reminds us that a culture of the feelings which is hostile to the intellect is itself suspect" (Robinson 1983, 206). Still, comparing the two poets, relatively far apart chronologically, one can contend that they were Romantics at heart, with Symbolism being more explicit in McAuley and Decadence and Expressionism in Trakl, although they were both fascinated by the German Der Blaue Reiter (The Blue Rider) journal group of Expressionist artists, especially the painters Franz Marc and Wassily Kandinsky. This holds true only for McAuley's late poetry which has been discussed here, and which can be related to his early poetic attempts. It is therefore interesting to see how, after decades of different preoccupations, he returned to his original poetic stance. Through Georg Trakl's Decadent strain and fin de siècle affiliations 
(George, Baudelaire, Rimbaud, since his strongest literary affiliation lies with this particular Symbolist French poet), whom McAuley translated into English in the collection Music in The Mirabell Garden: Georg Trakl, it is possible to establish James McAuley's fascination with these poets as well. James McAuley's collection Music Late at Night: Poems 1970-1973 published after his demise thus belongs to some of the finest verse he wrote. Trakl was a major literary influence on $\mathrm{McAu}$ ley's late poetry, whose verse was (linguistically and culturally) mediated through McAuley's verse translations of the Austrian poet, thus working both ways.

\section{Acknowledgment}

The author acknowledges the financial support from the Slovenian Research Agency (research core funding No. P6-0265).

\section{BIBLIOGRAPHY}

Baudelaire, Charles. "Une Charogne"/ "A Carrion", Flowers of Evil. Double-language edition by Wallace Fowlie. New York: Bantam Books Inc., 1963. 44-46. Coleman, Peter. The Heart of James McAuley. Sydney: Wildcat Press, 1980. . Coleman, Peter. The Heart of James McAuley: Life and Work of the Australian Poet (rev. ed.). Cleveland, Q1d.: Connor Court Publishing, 2006.

Gaffney, Carmel. "Music out of Decay: McAuley's Later Poetry and Georg Trakl”, Southerly, No. 4 (1976): 407-419. Revealing were also McAuley's comments on Trakl on ABC Radio in October 1973.

Harwood, Gwen. "Introduction to Music in the Mirabell Garden". Cf. Trakl.

Kramer, Leonie. James McAuley. St Lucia, Q1d.: University of Queensland Press, 1988.

Macainsh, Noel. "Music in the Mirabell", Quadrant, No. 19, September (1984): 18-23.

"The Late Poems of James McAuley", Southerly, No. 45/ 3, September (1985): 330-342.

McAuley, James. "The Poetry of Georg Trakl". The Grammar of the Real: Selected Prose 1959-1974. Melbourne: Oxford University Press, 1975.

. A Map of Australian Verse: The Twentieth Century. Melbourne: Oxford University Press, 1975.

. Music Late at Night: Poems 1970-1973. Sydney: Angus \& Robertson, 1976. Also contained in Time Given: Poems 1970-1976.

. Time Given: Poems 1970-1976. Canberra: Brindabella Press, 1976. 
. "Broken Incantation", qtd in Peter Coleman, The Heart of James McAuley. Sydney: Wildcat Press, 1980.

Page, Jean. "Writing from the Periphery: the Haunted Landscapes of James McAuley", Journal of the Association for the Study of Australian Literature, Vol 14, No 1(2014), https://openjournals.library.sydney.edu.au/index.php/JASAL/ issue/view/773.

Robinson, Dennis. "The Traditionalism of James McAuley". Australian Literary Studies, vol. 11, no. 2, (1983), doi: 10.20314/als.48d17f69b4.

Rowe, Noel. "James McAuley: The Possibility of Despair", Southerly 60.2 (2000): 26-38.

Shelley, Percy Bysshe. The Poems of Shelley. Thomas Hutchinson (ed.). London: Oxford University Press, 1961.

Trakl, Georg. Music in the Mirabell Garden: Georg Trakl; translations, images and songs [by] James McAuley, Larry Sitsky, John Olsen, Gwen Harwood. Hobart: University of Tasmania, The New Albion Press, 1982. Only 330 copies of the book were published, with hand-set text, printed by hand on goat-skin parchment with floriated initials.

Winter, John. "Printing James McAuley During the Falklands War", Westerly, No. 2, June (1989): 79.

\section{Zbirka Music Late at Night: Poems 1973-1976 Jamesa McAuleyja in poezija Georga Trakla}

Članek obravnava angleške prevode avstralskega pesnika Jamesa McAuleyja iz poezije avstrijskega pesnika Georga Trakla (1887-1914), kakor tudi Traklov literarni vpliv na McAuleyjevo lastno ustvarjanje v posthumni zbirki Music Late at Night: Poems 1970-1973. To velja predvsem za Traklovo pesniško zbirko prevedene poezije v angleščino Music in the Mirabell Garden, sicer pa nekatere zgodnje in pozne pesmi Jamesa McAuleyja prav tako kažejo močan pečat Traklove simbolistične in kasneje tudi ekspresionistične poezije.

Ključne besede: James McAuley, Georg Trakl, avstralska poezija 